\title{
Metachromatic leukodystrophy: pediatric presentation and the challenges of early diagnosis
}

\author{
Frederico Mendes Borges ${ }^{1}$ \\ Maria Júlia Gonzalez da Costa ${ }^{1}$ \\ (iD) Zumira Aparecida Carneiro ${ }^{1}$ \\ (iD) Charles Marques Lourenço ${ }^{1,2}$
}

1. Faculdade de Medicina - Centro Universitário Estácio de Ribeirão Preto, Ribeirão Preto, SP, Brasil. 2. CPDP - Centro Paulista de Diagnóstico, Pesquisa e Treinamento, Ribeirão Preto, SP, Brasil.

http://dx.doi.org/10.1590/1806-9282.66.10.1344

KEYWORDS: Leukodystrophy, Metachromatic/diagnosis. Child. Hereditary Central Nervous System Demyelinating Diseases.

PALAVRAS-ChaVE: Leucodistrofia Metacromática/diagnóstico. Criança. Doenças Desmielinizantes Hereditárias do Sistema Nervoso Central.

\section{INTRODUCTION}

Metachromatic leukodystrophy (MLD; OMIM 250100 ) is an autosomal recessive hereditary disease caused by a deficiency of the Arylsulfatase A (ARSA) enzyme and, more rarely, of Saposin B, which is responsible for the interaction with the sulfatide, allowing the ARSA to degrade it. Therefore, it is classified as a hereditary metabolic disorder that evolves with a reduction of sulfatide degradation. Initially, the disease was known as "diffuse cerebral sclerosis" and, in 1938, it was named "metachromatic leukodystrophy" and classified as a lipidosis in 1958 and 1959 , based on the discovery of a high concentration of sulfatídes (3-O-Sulfogalactosylceramide) (Figure 1) demonstrated by Jatzkewitz and Austin ${ }^{1.2}$.

ARSA deficiency causes metachromatic lipids to accumulate on the white matter of the central and peripheral nervous system, which is responsible for causing demyelination and may also affect organs
FIGURE 1. CHEMICAL STRUCTURE OF THE SULFATIDE (3-O-SULFOGALACTOSYLCERAMIDE).

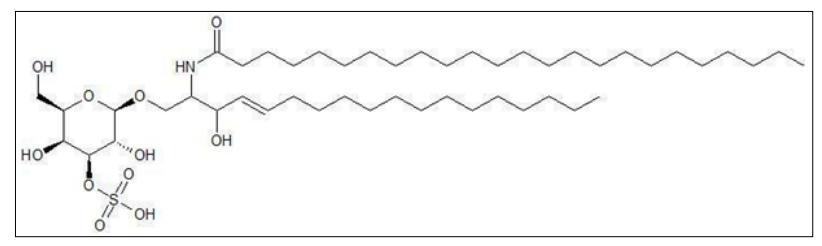

SOURCE: The authors, 2019.

such as the kidneys, gall bladder, spleen, and other visceral ones ${ }^{1-3}$. There are different variants (leading to different levels of residual enzymatic activity) and variations regarding the age of onset of the first symptoms and speed of disease progression, thus, it has been classified as: infantile (late infantile, 0 to 4 years), juvenile (4 to 15 years), and adult (over 15 years) (Annex $1)^{3.4}$. In addition, the diagnosis can be suspected when the patient begins to show signs of loss of intellectual, 
cognitive, and/or motor abilities, and it is possible to confirm it based on the dosage of the ARSA enzyme and sulfatídes (Diagram 1) ) $^{3.5}$.

The infantile type (late infantile) usually manifests during the second year of life, with a gait disorder of sudden onset as well when the child begins to learn to walk ${ }^{6}$. Often, an orthopaedist is sought before the neurological manifestations appear. Strabismus, dysarthria, spasticity, and intellectual deterioration appear gradually. Coarse tremors or coarse abnormal movements (athetosis) of the extremities may appear. The deep tendon reflexes of the lower limbs are reduced or absent ${ }^{7}$. In addition, spasticity episodes may be triggered by any feeling of discomfort (including constipation or cholecystopathy) and may result in severe episodes of stiffness and shaking, crying, sweating, and fever of unknown origin. During the third and fourth years of life, there is a rapid progression of the disease with the onset of visual abnormalities, such as optic atrophy and progressive amblyopia ${ }^{8.9}$.
The juvenile form, sometimes, can be divided into early and late ${ }^{10}$. The first is manifested between 4 to 6 years with abnormal gait and posture, emotional and behavioral disorders, ocular atrophy, and progressive spastic tetraparesis. The late juvenile type appears between the ages of 4 and 15 years, starting with more prominent behavioral abnormalities, poor school performance, and regression of language, followed by motor disorders and spastic tetraparesis that progresses more slowly ${ }^{3.10}$. Whereas in the adult type, two clinical presentations have been described: one was characterized mainly by signals from the central nervous system (pyramidal and cerebellar dystonia) and peripheral neuropathy, whereas the other clinical presentation begins with behavioral abnormalities, i.e., mood disorders, peculiar reactions in social interactions, progressive mental deterioration, and the presence of peripheral neuropathy may or may not be identified ${ }^{11}$. In these cases, an initial diagnosis of schizophrenia is established. Most of these patients

DIAGRAM 1. FLOWCHART FOR THE DIAGNOSIS OF METACHROMATIC LEUKODYSTROPHY.

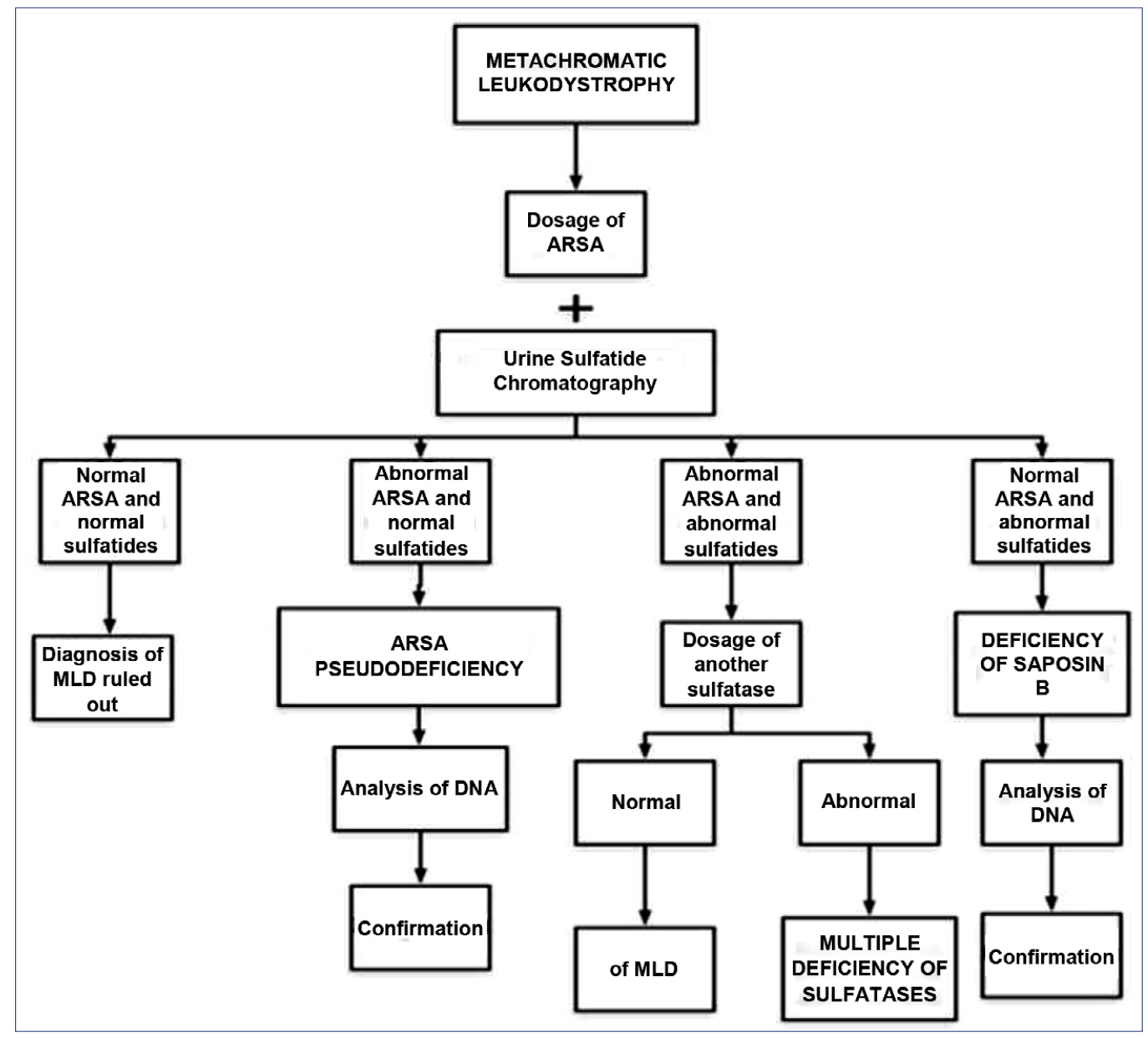


remain for several years without any other neurological symptom ${ }^{11.12}$.

We report a case series of patients with infantile MLD whose diagnosis was late due to little knowledge about the signs and symptoms of this group of diseases by the medical community.

\section{METHODS}

Review of clinical, laboratory, and neuroradiologic data of the sample of patients affected by metachromatic leukodystrophy at a referral center for the treatment of rare diseases in the state of São Paulo.

\section{RESULTS}

\section{Case 1}

Male patient, 6 years old, son of non-consanguineous parents. Born by cesarean delivery, at full-term. Presented, at birth, APGAR 9 in the $1^{\text {st }}$ minute and 10 in the $5^{\text {th }}$ minute, weighed $2700 \mathrm{~g}$ and head circumference of $35 \mathrm{~cm}$ (P50). At 2 years and 3 months, sought treatment with an orthopedist due to regression of gait associated with frequent falls and, at 3 years, started presenting regression of language and a complete inability to ambulate. Magnetic resonance imaging of the skull and an electroencephalogram (EEG) were requested, which presented the following abnormalities: abnormal white matter (diffuse alteration of myelinization with signs of axonal dysfunction and active myelin damage) and GEE compatible with diffuse encephalopathy. There was a suspicion of neurometabolic disease and, thereafter, exams were requested for the enzyme dosage of blood ARSA and the dosage of urine sulfatídes, which showed reduced activity of the ARSA enzyme and high concentrations of sulfatídes in urine, respectively. At 4 years and 4 months, the parents reported the onset of anorexia as a result of pneumonia, with the need for using gastrostomy in an attempt to improve the condition. Currently, the child weighs $11.3 \mathrm{~kg}$ and measures $93 \mathrm{~cm}$, BMI of $13.06 \mathrm{~kg} /$ $\mathrm{m}^{2}$ (P15), undergoes follow-up with a speech therapist and physiotherapist, and takes Carbamazepine, Oxcarbazepine, Simvastatin, Phenobarbital, N-acetylcysteine, Phosphoethanolamine,'1 Botulinum Toxin. Diagram 2.

\section{Case 2}

A female patient, 5 years old, daughter of consanguineous parents, was referred for neurologic evaluation due to a gait dysfunction. Pregnancy without intercurrences. G1P1A0C1. Born by cesarean delivery due to pelvic fetal presentation. Presented, at birth, APGAR 9 in the $1^{\text {st }}$ minute and 10 in the $5^{\text {th }}$ minute, weighed $3210 \mathrm{~g}$ (P50), measured $47 \mathrm{~cm}$, and $35 \mathrm{~cm}$ (P15) of head circumference. According to the curve of head circumference for the first 2 years of age, all markings were close to the P50 line. At 1 year and 9 months, upon presenting progressive difficulty in ambulation, a magnetic resonance imaging of the skull (Figure 2A) was completed, which showed no evidence of demyelination and presented all other parameters within normality. The mother reported that, at 2 years and 1 month, there was asthenia and regression of the ability to ambulate, even with assistance, and a gradual reduction of the volume of speech until it was completely lost. At 2 years and 3 months, there was asthenia of the cervical muscles and the onset of limb spasticity. Therapy with Sodium Valproate was prescribed, and the onset of frequent choking with liquids (water and medicines) was noticed. Thus, a diet of food pastes was started and, finally, a nasoenteral tube was used for 11 months. Frequent episodes of gastroesophageal reflux and aspiration pneumonia were reported in the following 3 months. At 3 years and 3 months, a Nissen surgery was carried out for the correction of reflux and gastrostomy. At 3 years and 9 months, a new magnetic resonance imaging of the skull (Figure 2B) was completed, which showed abnormal bilateral signal and symmetrical periventricular and subcortical white matter, supra- and infratentorial, conferring it a striped/tiger pattern appearance. Currently, the child weighs $17 \mathrm{~kg}$, is $105 \mathrm{~cm}$ tall, has a BMI of $15.419 \mathrm{~kg} / \mathrm{m}^{2}$, and takes Baclofen, Ranitidine, Levetiracetam, Risperidone, N-acetylcysteine, Phenobarbital, Beclomethasone, Montelukast, Lactulose, Budesonide. Diagram 2

\section{Case 3}

Female patient, 3 years and 9 months old, child of non-consanguineous parents. Presented, at birth, APGAR 9 in the $1^{\text {st }}$ minute and 10 in the $5^{\text {th }}$ minute, weighed $3400 \mathrm{~g}$ and measured $49 \mathrm{~cm}$, which placed her at the percentile 50 of age and height based on age. She was born with hypoglycemia, with suspected early sepsis, and was hospitalized in the ICU for 7 days. She was exclusively breastfed on free demand during the first six months. The patient presented normal neurological, psychological, and motor development up to the age of 2 years. She evolved to the inability to ambulate at 2 years and 4 months. At 2 years and 7 months, magnetic resonance imaging was completed, 

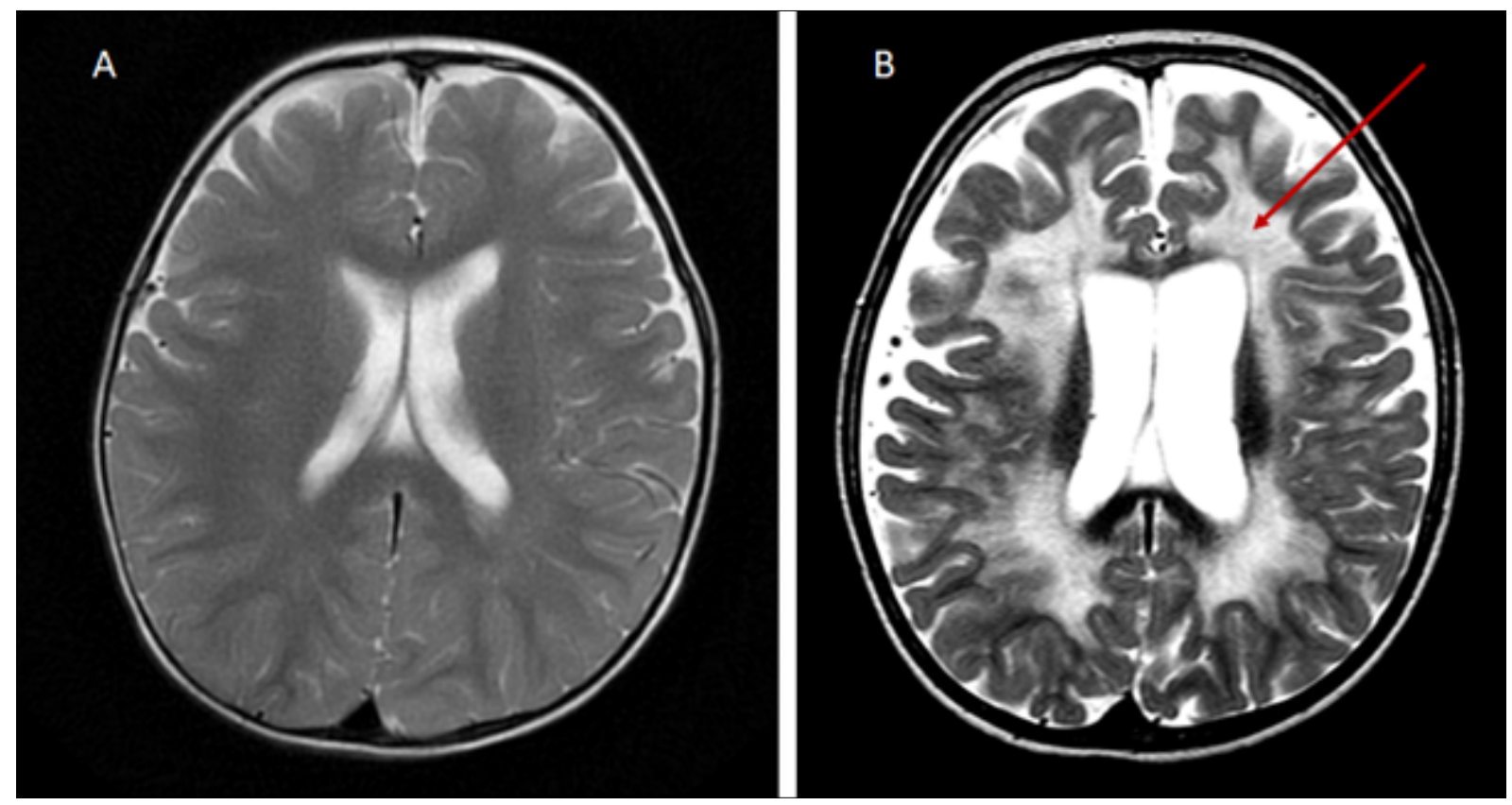

SOURCE: The authors, 2019.

which showed extensive abnormal areas in the white matter of the brain hemispheres, suggestive of cerebral metabolic disease. After imaging examination, CSF was collected, which showed demyelination. At 3 years, there was the onset of dysphagia for solid foods. Currently, the diet consists of food pastes. The mother reports that she underwent cesarean delivery, at 37 weeks, due to maternal diabetes and that there were no complications. The patient presents spasticity and,

DIAGRAM 2. COMPARISON BETWEEN THE PATIENTS REPORTED, BASED ON THE LEVEL OF CONSANGUINITY, ENZYME LEVEL OF BLOOD ARYLSULFATASE A, PATHOGENIC VARIANT, AGE OF INITIAL SYMPTOM, INITIAL SYMPTOM, AND AGE AT DIAGNOSIS.

\section{Late Infantile Presentation}

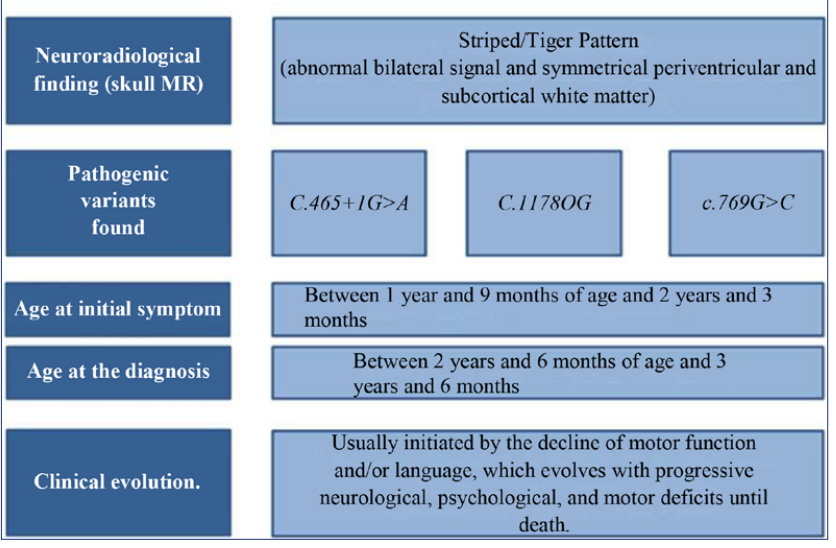

SOURCE: The authors, 2019 therefore, has recently undergone surgery to correct the shortening of the Achilles tendons in both lower limbs, associated with the use of Botox and orthoses. Currently, the child weighs $12.98 \mathrm{~kg}$, is $98 \mathrm{~cm}$ tall, is in the percentile 15 for height/age and below the percentile 5 for weight/age, has a BMI of $13.51 \mathrm{~kg} /$ $\mathrm{m}^{2}$ and takes Simvastatin, Vitamin D, Vitamin B12, Baclofen, Clonazepam, N-Acetylcysteine, Curcuma Longa (Zingiberaceae). Diagram 2

\section{DISCUSSION}

MLD is characterized by metachromatic granules produced by the accumulation of sulfatídes ${ }^{13}$. In this condition, the ARSA enzyme, which is coded by the ARSA gene, is abnormally present ${ }^{14}$. Patients with this condition can be classified based on the age of onset of the disorder. Up to 4 years of age, MLD is called "late infantile", at ages 4-15 years is referred to as "juvenile", and after the age of 15 years of age, as "adult"15. The three patients reported are classified as the late infantile presentation. Initially, MLD presents with focal neurological deficits, behavior disorders, and several other nonspecific signs and symptoms that make its early diagnosis a challenge $\mathrm{e}^{16}$.

In the late infantile presentation, at least $75 \%$ of the cases present the onset of symptoms, on average, prior to 18 months of age, while our study found that the first symptoms appeared only at 24 months on 
average $\mathrm{e}^{17}$. According to Kehrer et al. ${ }^{18}$, the initial clinical manifestations commonly described in the late infantile presentation are changes in muscle tonus, in particular in the lower limbs, which evolves to motor regression, present in $70 \%$ of the late infantile cases and in all 3 patients described in our study. In addition, the regression of speech and language is present in $2 / 3$ of our patients, compared to $48 \%$ of those affected by the late infantile presentation in the study analyzed. Another important factor to be emphasized is the time between the first symptoms and the date of the diagnosis. According to this same author, the average time between these parameters was 12 months in patients with the late infantile presentation, which was also observed in the present study. However, a greater time interval stands out in the patient of the second report, i.e., 2 years and 3 months from the initial symptoms until the diagnosis, which may affect the prognosis.

In the study by Barboura et al. ${ }^{19}$, two patients with the late infantile presentation showed MLD-characteristic lesions on the white matter of the periventricular region on magnetic resonance, similar to the findings of the study by Groeschel et al..$^{20}$, which also identified the same abnormality in their patients. We emphasize that, in addition to the demyelination affecting predominantly the periventricular region, it spares the subcortical area (U-fibers) of the white matter, as observed in the study by Barboura I and the present one. In addition, Groeschel et al. ${ }^{20}$ mention that the MRI images in the late infantile presentation are normal until the onset of the first symptoms. The same can be seen in the case of patient number 2 , who showed no signs of demyelination and other MLD patterns in the first magnetic resonance imaging completed.

In terms of laboratory exams, according to Van Rappard et al. ${ }^{21}$, the examination of the Arylsulfatase A enzyme activity should not be the only parameter since this may be low in cases of pseudo-deficiency of MLD alleles, which is caused by low enzyme activity but the patient presents no symptoms. With the examination of urine sulfatídes it is possible to distinguish it from actual ARSA deficiency since, if the results are positive, MLD is confirmed. In the study presented, the first two patients had reduced activity of the Arylsulfatase enzyme and in the examination of the third patient, the activity is undetectable. The statement by Van Rappard et al. ${ }^{21}$ corroborates the present study, supporting the understanding that complementary examinations are necessary to evaluate patients in all possible ways, which will contribute to an early diagnosis and improvement of their quality of life.

Even though there is still no curative treatment for this disease, new therapeutic possibilities are emerging, such as intrathecal enzyme replacement and hematopoietic stem-cell transplantation (HSCT) associated with gene therapy.

HSCT aims to treat the manifestations of MLD in the central nervous system; however, there are obstacles that still prevent it from being timely offered to patients because it preferably should be performed in a pre-symptomatic or oligosymptomatic phase with an allogeneic donor. Other obstacles consist in the identification of a HLA-compatible donor to minimize the risks of the procedure, such as graft-versus-host disease, and who should not be a carrier of pathogenic variants of $\mathrm{MLD}^{2}$. Although there has been a significant improvement in allogeneic transplantation, the therapy is still controversial since data from results are limited and difficult to generalize to the public affected due to the use of different eligibility criteria and transplantation protocols and different responses to its deployment with different presentations of MLD. In addition, transplantation cannot be offered to individuals with significant neurological involvement ${ }^{17.22}$.

Recently, advances have allowed combining HSCT with gene therapy. Gene therapy is the delivery of genetic material, using viral vectors, to the cells or tissues of an individual for therapeutic purposes. It is possible to modify stem cells and autologous hematopoietic progenitor cells using a lentivirus that expresses a functional ARSA enzyme, this is currently being tested in clinical trials with promising results. Studies have shown a reconstitution of ARSA activity in hematopoietic cells and in the cerebrospinal fluid. There is evidence of prevention of disease onset or interruption of its progression with the restoration of normal levels regarding motor function and the conduction of impulses in the peripheral nerves ${ }^{17.22}$.

Enzyme replacement therapy (ERT) is an alternative that benefits from the enzyme provision via the intrathecal route in patients with the late infantile presentation; it requires a trained neurosurgery team for the procedure to be performed and this method is not capable of enabling the patient to produce the enzyme ${ }^{23}$.

Unfortunately; none of the patients described could participate in the clinical studies previously described due to the late diagnosis when they already presented advanced and irreversible sequelae from the disease. 


\section{CONCLUSION}

In short, Metachromatic Leukodystrophy is a rare, devastating, and progressive hereditary disease. Given the possibility of emerging treatments specific to this illness, it is vital to obtain an early diagnosis. Even in the absence of specific therapies, the correct diagnosis allows the family genetic counseling and better therapeutic follow-up of patients to manage the complications from the disease.

\section{Author's Contribution}

All authors participated in the study design with substantial contributions to the concept and design, data acquisition, analysis, and interpretation, and drafting of the paper, with final approval of the version to be published, thus conforming to the uniform requirements of the International Committee of Medical Journal Editors.

\section{ANNEX 1. MLD PRESENTATIONS: CLINICAL MANIFESTATIONS, DIFFERENTIAL DIAGNOSES, AND LABORATORY} TESTS.

\begin{tabular}{|c|c|c|c|}
\hline Findings & Late Infantile Presentation & Juvenile Presentation & Adult Presentation \\
\hline Age of onset & Between 0 and 4 years & Between 4 and 15 years & From 15 years onward \\
\hline $\begin{array}{l}\text { Main clinical } \\
\text { manifestations }\end{array}$ & $\begin{array}{l}\text {-Developmental delay (gait, speech, etc.) } \\
\text {-Frequent falls } \\
\text {-Hypotonia } \\
\text {-Decreased or absent tendon reflexes } \\
\text {-Optic atrophy and nystagmus } \\
\text {-Epileptic seizures }\end{array}$ & $\begin{array}{l}\text {-Behavioral changes } \\
\text {-Learning difficulties } \\
\text {-Ataxia and frequent falls } \\
\text {-Extrapyramidal involvement } \\
\text {-Epileptic seizures }\end{array}$ & $\begin{array}{l}\text {-Behavioral changes (depression, } \\
\text { anxiety, etc.) } \\
\text {-Progressive dementia } \\
\text {-Ataxia } \\
\text {-Epileptic seizures }\end{array}$ \\
\hline Survival & From 6 months to 8 years & From 10 to 20 years & From 10 to 30 years \\
\hline $\begin{array}{l}\text { Main differential } \\
\text { diagnoses }\end{array}$ & $\begin{array}{l}\text { - Krabbe Disease } \\
\text {-Mitochondrial Encephalopathy } \\
\text {-Canavan Disease } \\
\text {-Alexander Disease } \\
\text {-Neuroaxonal Dystrophy }\end{array}$ & $\begin{array}{l}\text {-X-Linked Adrenoleukodystrophy } \\
\text {-Mitochondrial Encephalopathy } \\
\text {-Neuroaxonal Dystrophy } \\
\text {-Juvenile Krabbe Disease } \\
\text {-Juvenile Gangliosidoses (GM1 and } \\
\text { GM2) }\end{array}$ & $\begin{array}{l}\text {-Psychosis } \\
\text {-Neuropathies with a motor } \\
\text { predominance } \\
\text {-Adult Krabbe Disease } \\
\text {-Neuropathy, ataxia, and retinitis } \\
\text { pigmentosa (NARP) } \\
\text {-Adrenomyeloneuropathy }\end{array}$ \\
\hline $\begin{array}{l}\text { Image of the CNS } \\
\text { (MRI or CT) }\end{array}$ & $\begin{array}{l}\text {-Abnormalities in the periventricular and } \\
\text { centrum semiovale white matter } \\
\text {-U-Fibers are spared } \\
\text {-Beginning of the posterior pole in the } \\
\text { anterior direction }\end{array}$ & $\begin{array}{l}\text {-Abnormalities in the centrum } \\
\text { semiovale white matter } \\
\text {-Beginning of the anterior pole in } \\
\text { the posterior direction }\end{array}$ & $\begin{array}{l}\text {-Abnormalities in the centrum } \\
\text { semiovale white matter } \\
\text {-Beginning of the anterior pole in } \\
\text { the posterior direction }\end{array}$ \\
\hline
\end{tabular}

SOURCE: Adapted from Artigalas ${ }^{3}$

\section{REFERENCES}

1. Black JW, Cumings JN. Infantile metachromatic leucodystrophy. J Neurol Neurosurg Psychiatry. 1961;24(3):233-9.

2. The online metabolic and molecular bases of inherited disease. McGrawHill Medical [Internet]. [citado 24 de abril de 2019]. Disponível em: https:// ommbid.mhmedical.com/book.aspx?bookID=971

3. Artigalas OAP. Leucodistrofia metacromática: caracterização epidemiológica, bioquímica e clínica de pacientes brasileiros [Dissertação de Mestrado] Porto Alegre: Universidade Federal do Rio Grande do Sul; 2009. [cited 2019 Apr 23]. Available from: https://lume.ufrgs.br/handle/10183/29560

4. Marcão AM, Wiest R, Schindler K, Wiesmann U, Weis J, Schroth G, et al. Adult onset metachromatic leukodystrophy without electroclinical peripheral nervous system involvement: a new mutation in the ARSA gene. Arch Neurol. 2005;62(2):309-13.

5. Ribeiro E, Ribeiro M. Leucodistrofia metacromática: relato de caso de dois irmãos cosanguíneos. Rev Neurociências. 2014;21:580-6.

6. Artigalás $\mathrm{O}$, Lagranha VL, Saraiva-Pereira ML, Burin MG, Lourenço CM, van der Linden $\mathrm{H}$ Jr, et al. Clinical and biochemical study of 29 Brazilian patients with metachromatic leukodystrophy. I Inherit Metab Dis. 2010;33(Suppl 3):S257-62.

7. Kohlschütter A. Lysosomal leukodystrophies: krabbe disease and metachromatic leukodystrophy. Handb Clin Neurol. 2013;113;1611-8.

8. Oak S, Rao S, Karmarkar S, Kulkarui B, Kalgutkar A, Malde A, et al. Papillomatosis of the gallbladder in metachromatic leukodystrophy. Pediatr Surg Int. 1997;12(5-6):424-5.
9. Yavuz H, Yüksekkaya HA. Intestinal involvement in metachromatic leukodystrophy. J Child Neurol. 2011;26(1):117-20

10. IOS Press [Internet]. [citado 23 de abril de 2019]. Disponível em: https:// www.iospress.nl/book/differential-diagnosis-in-neurology/

11. van Rappard DF, de Vries ALC, Oostrom KJ, Boelens J), Hollak CE, van der Knaap MS, et al. Slowly progressive psychiatric symptoms: think metachromatic leukodystrophy. | Am Acad Child Adolesc Psychiatry. 2018;57(2):74-6.

12. Kumperscak HG, Paschke E, Gradisnik P, Vidmar J, Bradac SU. Adult metachromatic leukodystrophy: disorganized schizophrenia-like symptoms and postpartum depression in 2 sisters. | Psychiatry Neurosci. 2005;30(1):33-6.

13. Mancini GM, van Diggelen OP, Huijmans JG, Stroink H, de Coo RF. Pitfalls in the diagnosis of multiple sulfatase deficiency. Neuropediatrics. 2001;32(1):38-40.

14. Ozkara HA, Topçu M. Sphingolipidoses in Turkey. Brain Dev. 2004;26(6):363-6.

15. Developing Therapeutic Approaches for Metachromatic Leukodystrophy. Drug Des Devel Ther. 2013;7:729-45.

16. Mahmood A, Berry I, Wenger DA, Escolar M, Sobeih M, Raymond G, et al. Metachromatic leukodystrophy: a case of triplets with the late infantile variant and a systematic review of the literature. J Child Neurol. 2010;25(5):572-80. 
17. Gomez-Ospina N. Arylsulfatase A deficiency. 2006 May 30 [Updated 2017 Dec 14]. In: Adam MP, Ardinger HH, Pagon RA, et al., eds. GeneReviews ${ }^{\circledR}$ [Internet]. Seattle: University of Washington, Seattle; 1993-2019. Available from: https://www.ncbi.nlm.nih.gov/books/NBK1130/

18. Kehrer C, Groeschel S, Kustermann-Kuhn B, Bürger F, Köhler W, Kohlschütter A, et al; German LEUKONET. Language and cognition in children with metachromatic leukodystrophy: onset and natural course in a nationwide cohort. Orphanet J Rare Dis. 2014;9:18.

19. Barboura I, Hadded S, Chebel S, Mansour RB, Chahed H, Gueddiche MN, et al. Brain MRI and biological diagnosis in five Tunisians MLD patients. Diagn Pathol. 2012;7:11.
20. Groeschel S, Kehrer C, Engel C, Dali Cl, Bley A, Steinfeld R, et al. Metachromatic leukodystrophy: natural course of cerebral MRI changes in relation to clinical course. J Inherit Metab Dis. 2011;34(5):1095-102.

21. van Rappard DF, Boelens JJ, Wolf NI. Metachromatic leukodystrophy: disease spectrum and approaches for treatment. Best Pract Res Clin Endocrinol Metab. 2015;29(2):261-73.

22. Sessa M, Lorioli L, Fumagalli F, Acquati S, Redaelli D, Baldoli C, et al. Lentiviral haemopoietic stem-cell gene therapy in early-onset metachromatic leukodystrophy: an ad-hoc analysis of a non-randomized, open-label, phase 1/2 trial. Lancet. 2016;388(10043):476-87.

23. Rosenberg JB, Kaminsky SM, Aubourg P, Crystal RG, Sondhi D. Gene therapy for metachromatic leukodystrophy. J Neurosci Res. 2016;94(11):1169-79. 